\title{
Hi-tech Cultivation Practices in Papaya for Augmenting Productivity
}

\author{
J. Auxcilia ${ }^{1 *}$, S. K. Manoranjitham ${ }^{2}$ and M. S. Aneesa Rani ${ }^{2}$ \\ ${ }^{1}$ Department of Fruit Science, Horticultural College \& Research Institute for Women, \\ Trichy - 620 021, India \\ ${ }^{2}$ Department of Fruit Science, Horticultural College \& Research Institute, \\ Coimbatore - 641 003, India \\ *Corresponding author
}

\begin{tabular}{|l|}
\hline Ke y w o r d s \\
$\begin{array}{l}\text { Hi-tech cultivation } \\
\text { practices, Papaya, } \\
\text { Augmenting } \\
\text { productivity }\end{array}$ \\
\hline Article Info \\
\hline $\begin{array}{l}\text { Accepted: } \\
\text { 05 April } 2020 \\
\text { Available Online: } \\
\text { 10 May } 2020\end{array}$ \\
\hline
\end{tabular}

A B S T R A C T

Papaya (Carica papaya. L), gained momentum as a commercially and industrially important fruit crop in India. The demand for the fruits in the market is steadily increasing due to the awareness among public about its health benefits. India, though the world's largest producer of papaya, its cultivation is challenged by various factors such as Papaya Ring Spot Virus, Papaya mealy bug, root rot incidence, variations in seed propagation, malformation of fruits and lack of fruit set due to weather fluctuations, poor shelf life of fruits etc. To combat these problems, several technologies have been standardized like vegetative propagation through grafting, protocol for tissue cultured plants, balanced fertilizer application, integrated water and nutrient management practices, use of bio-fertilizers and bio control agents, adoption of precision farming practices viz., raised bed cultivation, fertigation, plastic mulching, micro nutrient foliar spray, besides management practices for Papaya Ring Spot Virus disease and nematodes which are reviewed in this paper.

\section{Introduction}

Papaya (Carica papaya L.) belongs to the family Caricaceae, has long been cultivated by the people in the home garden. Later, it has emerged as a commercial and industrial crop because of the vast utilization of papain in pharmaceutical and cosmetic industries. Papaya is native to Tropical America from where it has spread to most of the Caribbean and Asian countries during the $16^{\text {th }}$ century. In the $15^{\text {th }}$ century, it was introduced to Panama and from there to West Indies. In 1598, it was introduced in India via Malacca by Portuguese. Later it was introduced to China as an Indian Plant. It was reported in Zanzibar in $18^{\text {th }}$ century and in Uganda, it was reported during 1874. From there, it moved to Canada and USA. It is a dicotyledonous, polygamous diploid species with a small genome size of 
$372 \mathrm{Mb}$ (Arumuganathan and Earle, 1991). The importance of papaya to agriculture and the world's economy is well understood. It is now grown in all tropical and sub tropical countries like India, Brazil, Indonesia, Dominican Republic, Nigeria, Mexico, China, Taiwan, Thailand, Guatemala and various parts of Central and South Africa. India is the largest producer of papaya covering an area of 1.38 lakh ha, producing 59.89 lakh tonnes/ ha (Anon, 2018). It contributes $43.7 \%$ of the total world production. There is an increase in area from 73,100 hectares in 2001-02 to 1.38 lakh hectares in 2017-18, while the productivity increased from 35.1 t/ha to 43.2 t/ha. Tamil Nadu though have a lesser area under cultivation, 1.86, 1.90 and 1.53 thousand hectares, during 2015-16, 2016-17 and 2017-18, its productivity is higher viz., $229.74 \mathrm{t} / \mathrm{ha} 192.15 \mathrm{t} / \mathrm{ha}$ and $92.83 \mathrm{t} / \mathrm{ha}$ respectively.

In Australia, South Africa and India, there is a preference for dioecious varieties as they present certain heterosis which help to obtain high vigour and yield, besides papain. In India, Hawaii, Brazil, Taiwan and Southeast Asia there is also preference for gynodioecious varieties for local market as well as export market because of its excellent dessert quality.

Table.1 All India area, production and productivity of papaya

\begin{tabular}{|c|c|c|c|c|c|}
\hline Year & $\begin{array}{c}\text { Area } \\
\text { (IN ‘000 } \\
\text { HA) }\end{array}$ & $\begin{array}{c}\text { \%of total } \\
\text { frt. Area }\end{array}$ & $\begin{array}{c}\text { Production } \\
\text { (IN.'000 } \\
\text { MT) }\end{array}$ & $\begin{array}{c}\text { \% of Total FRT. } \\
\text { Production }\end{array}$ & $\begin{array}{c}\text { Productivity (in } \\
\text { MT/HA) }\end{array}$ \\
\hline $\mathbf{1 9 9 1 - 9 2}$ & 45.2 & 1.6 & 805.3 & 2.8 & 17.8 \\
\hline $\mathbf{2 0 0 1 - 0 2}$ & 73.7 & 1.8 & 2590.4 & 6.0 & 35.1 \\
\hline $\mathbf{2 0 0 2 - 0 3}$ & 68.0 & 1.8 & 2147.2 & 4.8 & 31.6 \\
\hline $\mathbf{2 0 0 3 - 0 4}$ & 58.2 & 1.2 & 1692.1 & 3.7 & 29.1 \\
\hline $\mathbf{2 0 0 4 - 0 5}$ & 73.8 & 1.5 & 2535.1 & 5.1 & 34.4 \\
\hline $\mathbf{2 0 0 5 - 0 6}$ & 67.8 & 1.3 & 2139.3 & 3.9 & 31.6 \\
\hline $\mathbf{2 0 0 6 - 0 7}$ & 72.0 & 1.3 & 2482.0 & 4.2 & 34.5 \\
\hline $\mathbf{2 0 0 7 - 0 8}$ & 83.0 & 1.4 & 2909.0 & 4.4 & 35.0 \\
\hline $\mathbf{2 0 0 8 - 0 9}$ & 98.0 & 1.6 & 3629.0 & 5.3 & 37.0 \\
\hline $\mathbf{2 0 0 9 - 1 0}$ & 95.7 & 1.5 & 3913.5 & 5.5 & 40.9 \\
\hline $\mathbf{2 0 1 0 - 1 1}$ & 106.0 & 1.7 & 4196.0 & 5.6 & 39.6 \\
\hline $\mathbf{2 0 1 1 - 1 2}$ & 117.4 & 1.8 & 4457.1 & 5.8 & 40.0 \\
\hline $\mathbf{2 0 1 2 - 1 3}$ & 132.2 & 1.9 & 5381.7 & 6.6 & 42.3 \\
\hline $\mathbf{2 0 1 3 - 1 4}$ & 133.4 & 1.8 & 5639.3 & 6.3 & 42.73 \\
\hline $\mathbf{2 0 1 4 - 1 5}$ & 114.97 & 1.9 & 4912.67 & 5.7 & 42.80 \\
\hline $\mathbf{2 0 1 5 - 1 6}$ & 132.41 & 2.1 & 5667.06 & 6.3 & 44.18 \\
\hline $\mathbf{2 0 1 6 - 1 7}$ & 134.44 & 2.1 & 5940.02 & 6.4 & 43.27 \\
\hline $\mathbf{2 0 1 7 - 1 8}$ & 138.40 & 2.1 & 5988.83 & 6.2 & \\
\hline
\end{tabular}

(Source: Horticulture Statistics Division, Department of Agriculture, Cooperation \& Farmers Welfare, Ministry of Agriculture \& Farmer's welfare, Govt. of India) 


\section{Nutrition and health benefits of papaya}

Papaya is a nutrition basket filled with vitamins, minerals, carbohydrates, proteins, iron, calcium and phosphorous. It is also a rich source of vitamins having an approximate composition of 2020 IU of vitamin $\mathrm{A}, 40 \mathrm{mg}$ of vitamin $\mathrm{B}_{1}$ and $46 \mathrm{mg}$ of vitamin $\mathrm{C}$ per $100 \mathrm{~g}$ of fruit (Dinesh, 2010). Papayas offer not only the luscious taste and vitamins, but are rich sources of antioxidant nutrients such as carotenes, vitamin C, flavonoids, folate, pantothenic acid and the minerals such as potassium, magnesium and fiber. Papaya has more carotene compared to other fruits such as apples, guavas and custard apple which help to prevent damage by free radicals. Ripe fruit is extensively used for table purpose and preparing jam, soft drinks, flavouring ice cream and candies. The unripe mature papaya fruit exudes milky latex when tapped is known as papain. It is a proteolytic enzyme and has great demand in the international market particularly in UK and USA. Papain is used in meat tenderization, manufacturing of chewing gum and for degumming silk. It also finds its use as cosmetics and as a drug for digestive ailments and used in the tanning industry too. Papain is also able to give shrink resistance to wool.

\section{Challenges in papaya cultivation}

India, though ranks first in papaya area and production, still lot of challenges which curtail the production which needs to be addressed. The climate change and associated challenges coupled with ever growing demand for qualitative/ quantitative production would have to be met through development of high yielding varieties along with better crop management practices. The following are the major challenges ahead with papaya production and productivity in India

The Papaya Ring Spot Virus (PRSV) and
Papaya Leaf Curl Virus ( $P a L C v)$ which is alarming affected productivity and quality of papaya fruits. From 2004 onwards, PRSV has becoming a major threat to papaya cultivation in Tamil Nadu

Papaya mealy bug emerged as an pest outbreak, now become a major menace which needs immediate attention

Seed propagation is though said to be quite easy, the thinning operation makes its cultivation difficult especially in dioecious papaya varieties

Papaya is sensitive to weather conditions. Weather aberrations like high temperature and low temperature adversely affecting the crop phenology and has impact on the crop production and profitability. This is more pronounced in gynodioeious varieties such as Co.7, Sun Rise Solo, Red Lady etc. exhibits disorders viz., stamen carpellody/cat face/malformation and summer-skip

Poor post harvest shelf life and lack of value addition pose problems towards marketing and realization of remunerative price

Though several works are being undertaken to develop varieties resistant to biotic and abiotic stresses, crop management practices are also being strengthened on the other side in order to sustain its productivity. The nutrients depleted by the biotic and abiotic stresses could be supplemented through précised crop management practices like water management, fertigation, organic and biofertilizers etc., so that the loss in fruit yield could be managed in a better way.

\section{Propagation}

\section{Seed propagation}

Since papaya is commercially grown by seed, 
production of quality seed is most important. In recent days, there exists demand for genuine papaya seed/seedlings among the growers. Private companies have been ventured on papaya seed and seedling production because of the increasing need. Seed dormancy has been reported in Papaya. Fresh papaya seeds exhibited dormancy up to a period of 35 days (Palaniswamy and Ramamoorthy, 1987). Seedlings are slender, stunted, and cannot survive long under conditions beyond soil EC $4 \mathrm{mmhos} / \mathrm{cm}$. (Makhija and Jindal, 1983). Anandha Kalaiselvi (1995) reported that soaking of seeds in $\mathrm{GA}_{3} 100$ ppm for 16 hours or pelleting of seeds with arappu leaf powder at $400 \mathrm{~g} / \mathrm{kg}$ using 10\% maida and adhesive and placing the seeds at $1 \mathrm{~cm}$ depth resulted in improved germination and enhanced seed vigour. Melvin et al., (2004) reported that seeds soaked in $0.1 \% \mathrm{KNO}_{3}$ solution produce seedlings that are more vigorous than seedlings from untreated seeds.

The growing media comprising of soil + compost + cocopeat $(1: 1: 1)$ along with $\mathrm{GA}_{3}$ $150 \mathrm{ppm}$ gave higher germination percentage, better shoot growth, better growth of tap root, secondary root production and chlorophyll content of seedlings of papaya cv. Coorg Honey Dew (Kumawat et al., 2014). Seeds soaked in $\mathrm{GA}_{3} 500 \mathrm{ppm}$ and $\mathrm{KNO}_{3}$ at $0.2 \%$ for 12 hours resulted in maximum germination, seedling height, number of leaves, stem diameter, leaf area, survival percentage in papaya hybrid 'Mayuri' at Allahabad (Barche et al., 2010).

In "TNAU Papaya Co.8", seeds treated with $\mathrm{KNO}_{3} @ 1.0 \%$ for 12 hours + sown in potting media comprising of Cocopeat + Vermicompost + Pseudomonas fluorescens + drenching the seedlings with $\mathrm{KH}_{2} \mathrm{PO}_{4} 1.0 \%$ at one month after sowing was adjudged as the best method for improvement of seed germination, seedling growth and vigour
(Donaka Dayeswari, 2016)

\section{A sexual propagation method}

Papaya, though conventionally propagated by seed for commercial plantations, its cultivation is hindered by problems due to the inherent heterozygosity and dioecious nature of the crop. Hence, conventional techniques of asexual reproduction such as grafting (Allan et al., 2010) and rooted cuttings (Rajan and Markose, 2007) have been tried at various places. In TNAU, Akino (2016) attempted to develop inter varietal (Carica papaya on Carica papaya) and intergeneric grafts of papaya where in Vasconcellea cauliflora was used as a root stock. The success percentage ranged from 80.00 to $82.50 \%$ on 10th day after grafting among the grafts and graft survival percentage ranged from 75.32 to $79.63 \%$ on 30th day. The inter-generic grafts though sprouted and survived in the nursery, failed to grow further in the main field. The earliest flowering (48.21 days) was observed in grafts of CO.7 on TNAU Papaya CO.8 followed by 59.69 days in grafts of TNAU Papaya CO.8 on TNAU Papaya CO.8, while the seedlings of CO.8 took the maximum number of days for flowering (122.31). The bearing height of the grafts was lower when compared to seedlings. Significant progress has been achieved in papaya mass multiplication through organogenesis and somatic embryogenesis (Litz and Conover, 1982). At TNAU, Sobhanandha Gummadi (2015) standardized tissue culture protocol for the dioecious variety TNAU Papaya Co.8 by collecting explants from male and female plants immediately after flowering at three months. She reported that both male and female plants responded similarly. Axillary buds recorded higher regeneration rates of 73.33 per cent compared to 60.00 per cent in shoot tips. The multiplication ratio was found to be 1:4, while MS medium 
fortified with $\mathrm{GA}_{3}$ could be a viable media for shoot elongation. Half MS medium fortified with IBA $(1 \mathrm{mg} / \mathrm{l})$ was effective for in vitro rooting.

\section{Precision farming techniques in papaya}

\section{Nutrient management}

In papaya, for better fruit production, a number of factors such as irrigation, nutrition, variety, spacing, climatic conditions etc. are responsible. Like any other crops, in papaya also integrated approach by nutrient and water management including usage of mulches and foliar nutrition is of great concern in the recent years. The discernable and the most frequent constraints are found to be related with irrigation and nutrient availability during the critical physiological phases. Papaya is an exhaustive crop requiring heavy and continuous supply of nutrients in order to sustain its high yield potential and also for its indeterminate growth habit with simultaneous leaf and fruit production (Purohit, 1993). Besides nitrogen, the plant height was also affected by phosphorus or potash application (Purohit, 1977). On contrary, Purohit (1984) also reported that the excess level of nitrogen resulted in significant reduction in plant height in papaya var. Coorg Honey Dew. Higher fruit weight and number with higher level of nitrogen and phosphorus application was also reported by Sulladmath et al., (1984). Biswas et al., (1989) observed a gradual increase in thickness of fruit pulp with increasing level of nitrogen application. Aneesa Rani (1995) obtained increased fruit number, fruit weight and fruit volume due to increased level of nitrogen and phosphorus fertilizers in CO. 6 papaya. In an experiment at South Africa, it was revealed that 'Solo' papaya showed a linear response to application of phosphorous from start of flowering to end of fruit set (Allan et al., 2000). He further reported that applied potassium exhibited quadratic response until end of fruit harvest and linear response thereafter. For Tamil Nadu, the current nutrient recommendation for papaya is bimonthly application of 50:50:50 g N: $\mathrm{P}_{2} \mathrm{O}_{5}$ : $\mathrm{K}_{2} \mathrm{O}$ from third month after planting which works out to $300 \mathrm{~g} \mathrm{~N}: \mathrm{P}_{2} \mathrm{O}_{5}: \mathrm{K}_{2} \mathrm{O} /$ tree/year (Anon, 2014). A fertilizer dose of $250 \mathrm{~g} \mathrm{~N}$, $250 \mathrm{~g} \mathrm{P}_{2} \mathrm{O}_{5}$ and $500 \mathrm{~g} \mathrm{~K}_{2} \mathrm{O} /$ tree /year is recommended to be applied in six equal splits at bi-monthly intervals for $\mathrm{Cv}$. Coorg Honey Dew at Karnataka (IIHR website). Bindu (2015) reported that application of 200:250:500g of $\mathrm{N}: \mathrm{P}_{2} \mathrm{O}_{5}: \mathrm{K}_{2} \mathrm{O}$ split at six equal doses at two months interval had a positive effect on fruit yield and high $\mathrm{BC}$ ratio in papaya under Kerala conditions. The requirement of all nutrients throughout the crop growth cycle of papaya is reported earlier (Kumar et al., 2010 and Bindhu, 2015).

\section{Irrigation and fertigation}

Papaya responds well to irrigation and adequate irrigation helps in fruit development and continuous fruit production. Irrigation with 50 to $75 \mathrm{~mm}$ water every 3-4 weeks is recommended and irrigating the plants at 1.3 times of the evapo-transpiration has been advised for papayas (Padmakumari and Sivanappan, 1989). Depletion of soil moisture reduced plant height, trunk diameter and the number of attached leaves per tree, and also retarded growth and development of papaya fruits (Masri et al., 1990). A serious yield reduction can occur if water shortage occurs at certain critical growth periods. Srinivas and Prabhakar (1993) observed that plants receiving frequent irrigation with 75 and 100 per cent evaporation replenishment maintained higher relative water content, transpiration rate, low diffusive resistance and higher yield in papaya cv. Coorg Honey Dew. Srinivas (1996) reported that in papaya cv.Coorg Honey Dew, increasing the 
evaporation-replenishment rates from 20 to 120 per cent increased the relative water content $(13.2 \%)$, transpiration rate $(18.8 \%)$, plant height $(21.9 \%)$, stem girth $(12.5 \%)$, fruit number $(88.3 \%)$, and fruit yield of papaya (34.6\%). Silva (1999) found that the highest growth and development rates for papaya trees with 120 per cent replacements of evapo-transpiration and lowest yields were obtained for replacements of 40 and 60 per cent of evapo-transpiration at two day irrigation intervals.

In papaya, the effects of interaction between the applied water depth and application frequencies resulted in linear growth of productivity with the increment in the applied water depth. However, it was verified that the largest productivity was obtained for irrigation frequency varying between three and five days. It was still observed that the average weight of fruits was practically not affected by the interval among irrigations, but this effect was observed for the number of commercial fruits per plant (Silva et al., 2001). Studies conducted by Sadarunnisa et al., (2010) indicated that $75 \% \mathrm{~N}$ and $\mathrm{K}$ when applied through drip recorded a yield of $100.42 \mathrm{~kg} / \mathrm{plant}$ which was at par with the yield of plants supplied with $100 \%$ RDF (102.60 kg/plant). Similarly, Jeyakumar et al., (2010) in papaya cv. CO 7, reported that application of 100 per cent recommended dose of $\mathrm{N}$ at $6.25 \mathrm{~g}$ week $^{-1}$ and $\mathrm{K}_{2} \mathrm{O}$ at $6.25 \mathrm{~g}$ week $^{-1}$ through drip irrigation in addition to soil application of $50 \mathrm{~g} \mathrm{P}_{2} \mathrm{O}_{5}$ in bi monthly intervals resulted in increase in number of fruits and fruit weight leading to higher fruit yield per tree $(73.97 \mathrm{~kg})$ and the resultant total fruit yield per hectare (184.9 tonnes).

\section{Use of mulches}

Use of plastic film has long been proved as an efficient technology for conservation of soil moisture, weed control etc. The black polythene film mulched plots had significantly lower soil temperature (1 to $2.8^{0} \mathrm{C}$ ) than the clear plastic film mulched plots. Because much of the solar energy absorbed by black plastic film mulch is lost to the atmosphere through radiation and forced convection (Schales and Sheldrake, 1963). The decomposition of organic residues under plastic mulch adds organic acids to the soil resulting in low soil $\mathrm{pH}$, which also increases the bioavailability of micro nutrients $(\mathrm{Mn}, \mathrm{Zn}$, $\mathrm{Cu}$ ad $\mathrm{Fe}$ ). Increased root zone temperature is one of the main benefits associated with use of plastic mulches. It also reduces some pests and diseases thereby the yield will be increased. In papaya var. TNAU Papaya Co.8, a study conducted on precision farming practices indicated that fruit yield was the highest $(73.45 \mathrm{~kg} /$ plant and 190.94t/ha) with treatment comprising of Raised bed cultivation + Drip irrigation (80\% ER) + Fertigation (75\% RDF) + micro nutrient spray $\mathrm{ZnSO}_{4} 0.5 \%+$ boric acid $(0.2 \%)$ at alternate months) followed by $59.20 \mathrm{~kg} /$ plant and $153.92 \mathrm{t} / \mathrm{ha}$ where in the treatment components were similar to the previous one but along with mulching with $100 \mu$ thick black polythene cover (Auxcilia et al., 2017)

\section{Foliar application of micro nutrients}

In papaya, the source sink capacity is also very high which warrants efficient manuring and supply of foliar nutrition too. Papaya is one such crop responds very well to micro nutrients especially Zinc and Boron as evidenced from the earlier studies conducted at TNAU and elsewhere. In papaya cv. Co-5, foliar spray of Zinc Sulphate at $0.5 \%$ with boron at $0.1 \%$ increased fruit weight, length, volume, circumference and latex yield, TSS and total sugars (Kavitha and Kumar, 2001). In papaya cv. Ranchi, maximum fruiting height $(99.67 \mathrm{~cm})$ and the lowest height of fruit setting $(82.33 \mathrm{~cm})$ were recorded with the foliar application of copper sulphate 0.25 
per cent + manganese sulphate 0.25 per cent + Borax 0.1 per cent followed by the foliar application of copper sulphate 0.25 per cent + Borax 0.1 per cent $(97.33 \mathrm{~cm}$ and $75.00 \mathrm{~cm})$ and the minimum with control. It might be due to combination of manganese with copper and boron which is believed to function in chlorophyll formation, caused rapid vegetative growth by which plant growth was promoted rapidly (Shekhar et al., 2010). In papaya var.Co.8, application of humic acid along with foliar spray of micronutrients @ $\mathrm{ZnSO}_{4}(0.5 \%)+\mathrm{FeSO}_{4}(0.5 \%)+\mathrm{MgSO}_{4}$ $(0.5 \%)+\mathrm{CuSO}_{4}(0.5 \%)+$ Boric acid $(0.1 \%)$ at $3^{\text {rd }}, 5^{\text {th }}$ and $7^{\text {th }}$ MAP + biofertilizers resulted in the highest fruit yield of $72.96 \mathrm{~kg}$ plant $^{-1}$ (Deepika, 2014).

\section{Biofertilizers and bio inoculants}

The benefits of employing biofertilizers were found in many crops including papaya. According to Aneesa Rani (1995) enhanced nitrate reductase, acid phosphatase, dehydrogenase and peroxidise activity in papaya cv. CO 6 as a result of application of Azospirillum, Phosphobacteria and AM fungi (a) 20,20 and 200g respectively per plant during 5th and 7th month after transplanting. They also observed increase in root length and root weight in plants treated with biofertilizers. A symbiotic interaction between arbuscular mycorrhizal (AM) fungi (Gigaspora and Glomus spp) was studied by (Khade and Rodriguez, 2009). Results revealed that, root colonization of AM fungi and mean root phosphates (acid and alkaline) activities recorded peak increase under $\mathrm{P}$ deficient, acidic soil conditions during all flowering stages of male papaya plants. In papaya cv. Surya, application of $50 \%$ recommended dose of fertilizers + FYM 15 $\mathrm{kg})+$ Azospirillum + PSB $(50 \mathrm{~g})+$ Vermicompost $(500 \mathrm{~g})$ respectively increased the quality parameters such as total carotenoids $(7.54 \mathrm{mg} / 100 \mathrm{~g})$, lycopene $(5.03$ $\mathrm{mg} / 100 \mathrm{~g}) \mathrm{TSS}\left(10.8^{\circ} \mathrm{Brix}\right)$ and ascorbic acid content of $280.67 \mathrm{mg} / 100 \mathrm{~g}$ (Reddy et al., 2012). Application of $100 \%$ RDF with AM fungi (250g/plant) + PSB (25g/plant) + Azospirillum (50g/plant) + T.harzianum (50g/plant) increased yield by $12.56 \%$ in papaya var. TNAU Co.8 papaya (Auxcilia et al., 2017)

\section{Biotic stress management practices}

Papaya ring spot virus is a serious viral disease transmitted by species of aphids. The virus affects production and productivity in every region. Raising maize as border crop and spraying Dimethoate $1.5 \%$ at monthly intervals up to 5 months after planting for vector control followed by application of $\mathrm{ZnSO}_{4} 0.5 \%$ and Boron $0.1 \%$ at $4^{\text {th }}$ and $7^{\text {th }}$ month after planting recorded the disease incidence of $18.60 \%$ with increased yield (87.8 $\mathrm{kg} / \mathrm{plant} /$ year) as compared to control where in the incidence was $96.0 \%$ and fruit yield reduced as $44.2 \mathrm{~kg} /$ plant/year respectively (Anon, 2009 and Anon, 2014). The incidence of Papaya Ring Spot Virus (PRSV) was the least (0.930, 1.003, 2.005 and $2.108)$ at $3^{\text {rd }}, 5^{\text {th }}, 7^{\text {th }}$ Months after Planting (MAP) with application of humic acid @ $2 \mathrm{ml} /$ plant at monthly interval from $1^{\text {st }}$ month up to $3^{\text {rd }}$ month, $3 \mathrm{ml}$ up to $5^{\text {th }}$ month and thereafter $4 \mathrm{ml} /$ plant up to harvest + Liquid Pseudomonas fluorescens soil application@ $5 \mathrm{ml} / \mathrm{plant}$ at $1 \mathrm{st}$ month, $10 \mathrm{ml} / \mathrm{plant}$ at $3 \mathrm{rd}$ month and $15 \mathrm{ml} /$ plant at $5^{\text {th }}$ MAP and $7^{\text {th }}$ MAP + foliar spray of salicylic acid @ 100 ppm at $3^{\text {rd }}, 5^{\text {th }}$ and $7^{\text {th }}$ month as foliar spray. The abiotic stress regulating enzyme activity viz., total phenols $(5.23 \mathrm{mg} / \mathrm{g})$ Phenylalanine Ammonia Lyase $(0.50 \mu \mathrm{g} / \mathrm{g} / \mathrm{hr})$ and Polyphenol Oxidase $(0.85 \mu \mathrm{g} \mathrm{min} / \mathrm{g})$ was the highest in the above treatment. (Deepika et al., 2005) Similarly, for control of nematodes in papaya, combined application of neem cake $250 \mathrm{~g}+$ carbofuran (1g ai) + Pseudomonas fluorescens (4 g) which gave maximum of 48 . 
$4 \%$ reduction in nematode population with higher fruit yield (88.5 fruit/plant) and fruit weight $(1.75 \mathrm{~kg} /$ fruit) in CO.2 papaya (Anon, 2006 and Anon, 2014).

\section{Way forward}

In Tamil Nadu Agricultural University and elsewhere in the country, précised nutrient and water management practices, besides bio formulations such as Azospirillum, Phosphobacteria, AM fungi, Pseudomonas fluorescens have been developed. Integrated management approaches for PRSV has been standardized at TNAU for papaya which is being disseminated through various media and programmes. Papain industries and processing industries for jam and tuity-fruity also encouraging farmers to invest on papaya cultivation. Due to awareness on consumption of papaya because of its health benefits the demand for the fruits in the market are also steadily increasing.

Though India occupies the prime position in papaya production, still certain issues needs to be addressed in order to solve the problems in the cultivation of papaya such as efficient water and nutrient management technique for PRSV, root-rot incidence in rainy season, problems related to high summer and winter in gynodioecious papayas such as summerskip and stamen carpellody. Post-harvest management practices, besides marketing strategies need special attention to get premium price to the farmers.

\section{References}

AICRP (TF) Proc.of GD Meet, 2006, Page No. 60,Tech. Doc. No.87, held at BCKV, Kalyani,West Bengal.

AICRP (TF) Proc.of GD Meet, 2009, Page NO.81, Tech.Doc.No.97, held at KAU, Thrissur.

Akino, 2016. Studies on production and evaluation of inter-generic and inter- varietal papaya grafts for growth and PRSV tolerance attributes. MSc. (Hort.) thesis submitted to Tamil Nadu Agricultural University, Coimbatore - 3 .

Allan P., C.Clark, M.Liang. 2010. Grafting Papayas (Carica Papaya L.) Acta Hort., 851:254.

Allan, P., N.J. Taylor and H.M. Dicks. 2000. Fertilization of "Solo" papayas with nitrogen, phosphorus and potassium. Acta Horticulturae, 511: 27-33.

Ananthakalaiselvi, A. 1995 Seed technological studies for begetting quality seeds in Papaya (Carica papaya L.) M.Sc (Agri.) Thesis, Tamil Nadu Agricultural University, Coimbatore.

Aneesa Rani, M.S. 1995. Integrated nutrient management of nitrogen and phosphorus in Co 6 Papaya (Carica Papaya L.) M.Sc. (Hort.) Thesis, Tamil Nadu Agricultural University, Coimbatore.

Anon, 2006, AICRP (TF) Proc.of Group Discussion Meet, 2006, Page No. 60, Tech. Doc. No.87, held at BCKV, Kalyani, West Bengal.

Anon, 2009. AICRP (TF) Proc.of Group Discussion Meet, 2009, Page No.81, Tech.Doc.No.97, held at KAU, Thrissur.

Anon, 2014. Crop Production Guide 2014. Jointly published by Directorate of Horticulture and Plantation Crops and Tamil Nadu Agricultural University, Coimbatore-3

Anonymous, 1999. Crop production manual for horticultural Crops, Department of Horticulture,Govt. of Tamil Nadu, Chennai and Tamil Nadu Agricultural University, Coimbatore.

Anonymous, 2018. Horticultural Statistics at a Glance, Ministry of Agriculture and Farmers welfare, Government of India, Department of Agriculture, Cooperation \& Farmers' Welfare, Horticulture Statistics Division.

Arumuganathan, K. and E. D. Earle. 1991. Estimation of nuclear DNA content of plants by flow cytometry. Plant molecular biology reporter: 9(3): 229-241.

Auxcilia, J., K.Soorianathasundaram, K.B. 
Sujatha, P. Muthulakshmi and R.M. Vijayakumar. 2017. Evaluation of precision farming practices in papaya for enhanced productivity. In Abs. of National congress on New challenges and advances in sustainable micro irrigation held at water technology centre, TNAU, Coimbatore from 1-3, March, 2017

Auxcilia, J., Manoranjitham, $\mathrm{K}$ and $\mathrm{K}$. Soorianathasundaram. 2017. Role of biofertilizers in

Auxcilia, J., Manoranjitham, $\mathrm{K}$ and $\mathrm{K}$. Soorianathasundaram. 2017. Role of biofertilizers in improving productivity of papaya. (In Tamil), In Souvenir of Third National Conference on Agricultural Scientific Tamil, held at Tamil Nadu Agricultural University in August 12-13, 2017.

Barche, S., K.S. Kirad and D.B.Singh. 2010. Response of seed treatment on germination, growth, survivability and economics of different cultivars of papaya. Acta Horticulturae., (851): 279- 284.

Bindu, B.2015. Nutrient requirement of papaya (Carica papaya.L): A study for enhancing fruit production. Indian Journal of Research: 4(3):6-7

Biswas, B., S.K. Sen and S.C. Maity. 1989. Effect of different levels of nitrogen and potassium on growth yield and quality of papaya var. 'Ranchi'. Haryana J. hort. Sci., 18 (3-4): 197-203.

Deepika C. Auxcilia, J. Durga Devi, D. and M. Jagadeesha, 2005. Effect of organic and inorganic growth stimulants on biotic stress regulating enzymes and papaya ring spot virus incidence of TNAU Papaya Co.8. (Carica Papaya L.) Progressive Research - An International Journal, Volume 10 (Special-III) : 1424-1428.

Deepika, C.2014. Influence of organic and inorganic growth stimulants on growth, yield and quality of TNAU Papaya Co.8 (Carica papaya. L). M.Sc. (Hort) thesis submitted to Tamil Nadu Agricultural University, Coimbatore -3 .

Donaka Dayeswari.2016. Studies on improvement of seedling vigour in TNAU $\begin{array}{llll}\text { Papaya } & \text { CO.8 (Carica papaya L.). }\end{array}$ M.Sc.(Hort.) thesis submitted to Tamil Nadu Agricultural University, Coimbatore -3 .

Enhancing productivity of papaya (in Tamil). In $3^{\text {rd }}$ National level Tamil seminar on Agricultural Research, organized by TNAU \& Agricultural Scientific Tamil Society, held at TNAU from August 12-13, 2017. pp: 267-269

Jeyakumar, P., R. Amutha, T.N. Balamohan, J. Auxcilia and L. Nalina. 2010. Fertigation improves fruit yield and quality of papaya. Acta Hort., 851: 369-376.

Kavitha, M and N.Kumar, 2001. Effect of zinc and boron on biochemical and quality characters of papaya cv. CO.5. South Indian Hort., 48 (1-6): 1-5

Khade, W and B.F. Rodriguez. 2009. Applications of arbuscular mycorrhizal fungi in Agro ecosystems. Tropical and Subtropical Agroecosystems, 10: 337 354.

Kumar, N., K. Soorianathasundaram, N.Meenakshi, M.I. Manivannan, J. Suresh, V. Nosov, 2010.Balanced fertilization in papaya (Carica papaya, L) for higher yield and quality. In Proc.of the International symposium on papaya. Acta Horticulturae: 851: 357-360

Kumawat, A., B.L. Pareek, R.S. Yadav and P.S. Rathore. 2014. Effect of integrated nutrient management on growth, yield, quality and nutrient uptake of Indian mustard (Brassica juncea) in arid zone of Rajasthan. Indian J. Agron., 59(1): 119123.

Litz, R.E. and R.A. Conover.1982.Root production and plantlet development in tissue cultured papaya. Am.J.Bot., 42:5355.

Makhija, M. and P.O. Jindal. 1983. Effect of different salinity level on seed germination and seedling growth in papaya (Carica papaya $\mathrm{L}$ ) seed res., 11: 125-128.

Masri, M., A.S. Razak and M.Z. Ghazalli. 1990. Response of papaya (Carica papaya L.) to limited soil moisture at reproductive stage. Mardi Res. J., 18: 191-196. 
Melvin, S, L. Nishina, Mike A. Nagno and Sheldon C. Furutani, 2014. Optimizing germination of papaya seeds. Department of Tropical plant and soil sciences, CTAHR, UH-Manoa and College of Agriculture, Forestry and National Resource Management, UH-Hilo. Fruits and Nuts -8 .

Padmakumari and R.K. Sivanappan. 1989. Drip irrigation for papaya. In: Engineering 1. Land and water use (eds. Dodd, V. A. and K. M. Patric) pp. 669-671.

Palanisamy, V. and K. Ramamoorthy. 1987 Seed germination studies in papaya. Prog. Hort., 19 (93-4): 253-255.

Purohit, A.G. 1977. Response of Papaya (Carica Papaya L.) to nitrogen, phosphorus and potassium. Indian J.Hort., $34: 350-353$.

Purohit, A.G.1984. Studies on growth, yield and nutrition of papaya. In: Proc. of National Seminar on Papaya and Papain production. Faculty of Horticulture, TNAU, Coimbatore.pp.64-69

Purohit, A.G.1993. Papaya nutrition. Advances in Horticulture 2 (Fruit Crops part 2): 906913

Rajan, S., B.L. Markose 2007.Propagation of horticultural crops. Hort. series 2:16.

Reddy, N., S.R.S. Prasad, R.M. Kurian, A.N. Ganeshmurthy and P. Pannerselvam. 2012. Effect of organic practices on fruit quality in papaya cv. Surya. J. Hort Sci., 7(9):8890.

Sadarunnisa, S., C. Madhumathi, K. Haribabu, B. Sreenivasulu and M. Rama Krishna. 2010. Effect of fertigation on growth and yield of papaya cv. Red lady. Acta Hort., 851: 395-400.

Shekhar, Chandra, Yadav, A.L., Singh, H.K. and Singh, M.K. (2010). Influence of micronutrients on plant growth, yield and quality of papaya fruit (Carica papaya L.) cv. WASHINGTON, Asian J. Hort., 5 (2) : 326-329.

Silva, J.G.F. 1999. Effect of different depth and frequency of irrigation on the development and production of papaya (Carica papaya L.). Ph.D., Thesis in water resources submitted to Federal University of Vicosa.

Silva, J.G.F.DA., Paulo Afonso Ferreira, Luiz Cláudio Costa, Raúl Renné Valle Melendes and Paulo Roberto Cecom. 2001. Effects of different water depths and irrigation frequencies on the yielding of papaya tree (Carica papaya L.). Rev. Bras. Frutic., 23(3): 597-601.

Sobhananda Gummadi, 2015. Standardization of in vitro regeneration protocol for mass multiplication of the dioecious variety "TNAU papaya CO 8"(Carica papaya .L)". MSc. (Hort.) thesis submitted to Tamil Nadu Agricultural University, Coimbatore -3

Srinivas, K. 1996. Plant water relations, yield, and water use of papaya (Carica papaya L.) at different evaporation-replenishment rates under drip irrigation. Trop. Agric., 73(4): 264-269.

Srinivas, K. and M. Prabhakar. 1993. Plant water relations, yield, and water use of papaya (Carica papaya L.) in relation to irrigation to irrigation and nitrogen fertilization. Singapore J. Primary Industries, 21(1): 1-5.

Sulladmath, U.V., J.V.Narayanagowda and S.V.Ravi. 1984. Effect of nitrogen, phosphorus and potassium on yield and quality of Papaya cv. 'Solo'. In: Proc. of National Seminar on Papaya and Papain production. Faculty of Horticulture, TNAU, Coimbatore. p. 70-74.

\section{How to cite this article:}

Auxcilia, J., S. K. Manoranjitham and Aneesa Rani, M. S. 2020. Hi-tech Cultivation Practices in Papaya for Augmenting Productivity. Int.J.Curr.Microbiol.App.Sci. 9(05): 636-645. doi: https://doi.org/10.20546/ijcmas.2020.905.070 